\title{
Loan growth and bank solvency: evidence from the Pakistani banking sector
}

\author{
Muhammad Kashif*, Syed Faizan Iftikhar and Khurram Iftikhar
}

\author{
* Correspondence: \\ kashifdewan@hotmail.com \\ Applied Economics Research \\ Centre, University of Karachi, \\ Karachi, Pakistan
}

\begin{abstract}
Background: The dramatic loan growth and changes in the Pakistani banking system in mid-2000s have led to significant research attention on borrowers and lenders. This expansion and diversification in financial sector was driven by structural reforms, political stability and significant economic growth. Against this background, this study investigates the loan growth and risk-taking behavior of the banks during the expansionary periods of lending.

Method: This study used dynamic two-step system generalized method of moment's estimation technique, based on data taken from 32 banks in Pakistan over 2006-2014.

Result: Loan growth has a significant effect on bank-specific and macroeconomicspecific variables. Loan growth in the previous year raises non-performing loans and decreases the solvency of banks with a time lag of many years. The driving force behind this phenomenon is weak prudential regulation among competitors, the asymmetric information of the borrowers, and, most importantly, that banks underestimate the risk of lending during credit booms.
\end{abstract}

Conclusion: More regulatory measures are required to ensure a strong financial system when the volume of non-performing loan grows significantly. An increase in the capital requirement policy for rapidly growing banks is also needed because the problem of abnormal loan growth cannot be detected at the current time. At the same time, strong supervision is necessary to avoid the adverse consequences of borrower selection.

Keyword: Loan growth, Non-performing loans, Bank solvency

JEL Classification: G20, G21

\section{Background}

Banks allocate their savings to competitive firms, entrepreneurs, individuals and governments to enhance capital accumulation and profitability. Bank based financial systems channel their funds from depositors to borrowers through financial intermediaries (Levine 2002). In global economy, the importance of financial sector cannot be understated because finance spurs growth, increases livelihood and strengthens the infrastructure. Indeed, empirical research has confirmed that financial deepening is one of the driving forces behind economic growth. ${ }^{1}$

However, debate on the benefits of financial liberalization and lending booms is always a critical issue among the researchers because of their complex and non-linear relationship. Allen and Gale (2003) argue that financial liberalization triggers the lending growth and increases economy-wide output at the equilibrium owing to the cost of

(C) The Author(s). 2016 Open Access This article is distributed under the terms of the Creative Commons Attribution 4.0 International License (http://creativecommons.org/licenses/by/4.0/), which permits unrestricted use, distribution, and reproduction in any medium, provided you give appropriate credit to the original author(s) and the source, provide a link to the Creative Commons license, and indicate if changes were made. 
crisis. Similarly, Foos et al. (2010) revealed that growth in abnormal loans in previous years is directly associated with loan losses at both the aggregate and individual bank level, while Gourinchas et al. (2001) found a weak relationship between lending booms and crisis outside Latin America. Therefore, lending growth enhances the financial deepening and competition, which raises the efficiency and reduces the cost of borrowing. ${ }^{2}$

Like other businesses, financial institutions and banks expand their loan magnitude to generate more earning or profits. In other words, the availability of debt capital for companies and entrepreneurs develops new businesses. Lending money to local companies can also increase the profit of local economies as well as local employment. However, if the trend of loan expansion is aggressive, the chance of loan losses is higher, too. Altunbas et al. (2010) found that households, firms and banks usually underestimate risk to earn higher profits, increasing the probability of future problems. Furthermore, an unstable economy or underpricing by banks can also cause of higher loan losses. Several studies have highlighted the risk associated with excessive bank lending that lead to higher loan losses, which affects financial systems and entire economies.

As a facilitator for both borrower and the lender, vibrant banking system in Pakistan makes it possible for manufacturers and industries to enhance their field of operations and potential markets for their products. After undergoing recent reforms and privatization, the dramatic subsequent changes in the Pakistani banking system have attracted significant attention from both researchers and financial managers. The number of borrowers increased markedly because of increased financial activity and sound and stable economic conditions in mid-2000s. Owing to the economic stability to all sectors of economy, banks began to provide individuals and businessmen with convenient and easy access to services, which increased the efficiency and outputs (see, eg, Rajaraman and Vasishtha 2002).

Against this background, this study examines whether higher loan growth always lead to higher loan losses in the context of stable economy. We also observe the behavior of banks when they expand their financial statements. Numerous studies describe the consequences of abnormal loan growth; therefore, if growing financial sector in developing countries such as Pakistan uses the experiences of bank-based economy, it will help in future. Furthermore, this is very important during this transition period, when the Pakistan is looking to enhance the banking services and facilities to its entire population.

In particular, we examine the relationship between loan growth and risk taking behavior of the banks and discuss the impact of loan growth on financial health. To evaluate different views on the relationship between credit growth and banks' risk-taking behavior, this study uses micro level panel data on 32 banks over 2006-2014. To understand the effect of loan growth on financial system, we use two-step system GMM (generalize method of moments) estimation technique. This study thus contributes to the banking and finance literature in two main ways. First, it investigates the relation between loan growth and riskiness of banks using balance sheet data of individual bank. Second, along with bankspecific variables, this study also considers macroeconomic-specific variables. However, this study goes one step further by examining the effect of rule of law during the expansion of lending growth.

Our findings, therefore, provide important insights to regulators into the riskiness and stability of the Pakistani banking system during a period of excessive lending growth. The remainder of the paper is organized as follows. Related literature section 
provides a literature review. We discuss the data and definite the variables in Data sources and defeinition of variables section. Then, Empirical framework section presents the hypotheses and the empirical framework. Empirical results section reports the empirical results and Conclusion section concludes.

\section{Related literature}

Bank loan is an important source of funding for borrowers (eg, households and firms). However, a country with an underdeveloped capital market relies less on external funding as compared with a developed capital market. The external source of funding in financialbased economies is bank credit. The availability of loans and credit flows plays a vital role and provides funds for investment and refinancing. Moreover, endogenous growth theory states that financial liberalization and credit growth put the positive impact on economic indicators in long run (See Bencivenga and Smith 1991). However, excessive credit expansions can adversely influence bank riskiness. Several studies documented that the loan growth has significant effect on financial health. For instance, Amador et al. (2013) used a panel data approach to reveal abnormal loan growth and risk taking behavior of financial institutions in Colombia. The results suggested that persistent growth in abnormal loan leads to a notable increase in the ratio of non-performing loan (NPLs) to total loan, with solvency found to be significantly negative in the long run.

Similarly, Messai and Jouini (2013) examined the determinants of non-performing loans (NPL) in Spain, Italy and Greece in 2004-2008, finding that NPLs rise when bank increased their provision and that return on bank assets has a negative impact on NPLs. Foos et al. (2010) used bank scope data on 16,000 banks in 16 major countries for 19972007, finding that growth in previous abnormal loan is directly associated with loan losses at aggregate level and individual bank level. Moreover, excessive loan growth adversely affects bank interest income which decreases the profitability. On the contarary, extensive growth in loan reduces the capital ratio which shows negative effect on solvency.

Baradwaj et al. (2014) investigated the impact of lending growth on the riskiness of Chinese banks from the period of 1992-2007. Their findings indicate that growth in lending increases in loan loss provisions, interest income, but lower capital ratios. Furthermore, results suggested that loan growth represents an important driver of the riskiness of banks. Likewise, Sinkey and Greenwalt (1991) examined the loan loss experience and risk taking behavior of large commercial banks in the United States between 1984 and 1987 and found the strongest variation in the loans loss rate at the regional level. The results indicate that loan loss rates have positive relation with loan volume, loan rate and volatile funds from preceding years.

Dell'Ariccia and Marquez (2006) examine the bank's lending behavior, standard, mechanisms of credit allocation under the informational structure of borrower creditworthiness. They found that during lending boom, banks' managers change the information structure and lend to risky borrower or use asymmetries information on borrowers. Such easy lending impairs banks' portfolios, results in unusual credit growth, decreases banks' profits and raises the risk of financial instability. Similarly, Salas and Saurina (2002) investigated the determinants of Spanish commercial banks' and saving banks' decision to lend for 1985-1997. They revealed expansion in credit, exploration of new markets and managerial leniency toward borrower creditworthiness determine future loan losses. They also suggested that rising loan growth, a large network of branches and a reduction in the 
interest margin are early sign of future loan losses. ${ }^{3}$ Leaven and Majnoni (2003) suggested that the relation between the loan loss provision and loan/GDP growth is negative, while the bank earnings ratio has a positive and significant impact on loan loss provision. Similarly, Hess et al. (2009) analyzed Australian banks during 1980-2005 and reported that credit losses increased under weak macroeconomic conditions and that large banks suffered higher credit losses due to their large market share compared with smaller banks. Cucinelli (2015) also concludes that lending by the banks reduced because of the fear of credit risk during a financial crisis, while the GDP growth rate shows a positive impact on the bank lending behavior. Pelozo (2008) suggested that institutional modification and structural changes reduce systematic risk in financial sectors, which encourages efficiency and solvency. Finally, Tahir et al. (2015) examined the nexus of bank credit to the private sector and economic growth in Pakistan and suggested that bank credit has an adverse impact on economic growth.

\section{Data sources and defeinition of variables}

This study analyzes micro-panel data on 32 banks in Pakistan between 2006 and 2014. The data on bank-specific determinants including NPLs, solvency, loan growth, bank assets, the efficiency ratio and the leverage ratio are collected from the State Bank of Pakistan and the balance sheets of individual banks. The data on macroeconomics variables, such as inflation, real GDP, unemployment and rule of law are drawn from the Economic Survey of Pakistan and World Development Indicators database. The inclusion of macroeconomic factors in the model is important as variables such as (inflation, unemployment, GDP growth and rule of law) have direct or indirect non-linear relationships with the bank-specific variables. The dynamics of inflation rates discourage a firm's potential to generate a higher profit, decrease private credit and hamper financial development, while the availability of credit positively influence real GDP (see Tinoco-Zermeño et al. 2014). Changes in the unemployment rate cause a contraction or expansion in the reimbursing capacity of households; however, an increase in unemployment reduces the repayment capacity of loans, which raises the default rate. Governance in developing countries is also an important indicator of financial health, as markets influenced by weak institutions and a loose rule of law lead to a low level of investor confidence and reduce profitability and efficient performance. The Asian financial crisis of 1997-1998 showed the effect of poor firm-level governance and unstable institutions (Johnson et al. 2000).

\section{Bank-specific variables}

NPLs to Gross Advances express the quality of the loan portfolio of a bank. It represents the percentage of defaulting loans or NPLs (debtor scheduled payments is overdue by 90 days or more) as gross advances made by a bank and evaluates asset quality based on the loan portfolio. This ratio is often used as a proxy for asset quality to identify problems in the loan portfolio.

Solvency is measured by the ratio of total capital (sum of tier1 and tier2 capital) to risk-weighted asset, which reflects the strength of a bank. Although abundant capital has the ability to absorb credit market shocks, higher bank capital typically accelerates risky credit activities, which results in loan losses. On the contrary, a low level of 
capital places pressure on banks' managers to accumulate more assets and returns, which may raise loans losses.

Bank size is estimated by using total assets. Growing banks have a high concentration of market activities, pursue lending diversification, focus on consumer financing and are unconcerned about the asymmetric information of borrowers. Thus, we expect the relationship between bank assets and NPLs is to be negative.

Loan growth expresses the change in the current year's loans as a percentage of those of the previous years. The ultimate objective of credit creation is to raise profit and market share. However, fragile business models and the leniency of managers in the selection of borrowers usually reduce loan effectiveness.

The Leverage ratio is defined as the percentage of total equity to total assets. A higher ratio indicates that a bank is well capitalized. The leverage ratio allows a bank to use its funds through direct investment for potential gains. Beyond the fear of loan consequences, banks use this opportunity to acquire more assets with the aim of higher return on equity. The leverage trend is pro-cyclical: it increases in boom years and reduces in periods of financial turmoil.

The ratio of non-interest expenses to total assets is used to measure the efficiency ratio and a bank's overheads, which indicates that the higher the ratio, those worse is efficiency. Non-interest expenses include employee salaries and benefits, taxes, professional service fees, equipment and property leases and loan loss provisions. If the loan loss provision rises due to bad loan growth, NPLs increase.

\section{Macroeconomic variables}

GDP growth reflects the direction of economic progress. Promising economic growth enhances the income of households and other businesses. Favorable market activity encourages lending, and borrowers then have sufficient reserves to facilitate their debts. Since borrower usually default three of more years later and loan losses are anticipated to increase during economic slowdown (eg, Foos et al. 2010). Therefore, we expect a negative relationship between NPLs and economic growth.

Unemployment's relationship with NPLs has been shown to be positive (Nkusu 2011; Bofondi and Ropele 2011 and Berge and Boye 2007). Theoretically, when the unemployment level rises in a country, it harms an individual's income and increases the debt burden. Furthermore, when an individual loses his or her source of income, loan repayment becomes problematic in the future. Similarly, the sales and manufacturing activities of firms are also affected by unemployment because their low purchasing power leads to a decline in revenue and increases debt (Louzis et al. 2010).

Inflation is also used as a control variable. Marijana Curak et al. (2013) defined stable prices and a low level of inflation as indicating growing economy, which raises the capacity of debtors to repay loans. Price instability leads to a decline in the real value of debt and makes it easier for debtors to repay their loans. Moreover, the real value of income decreases during high inflation; this shows weak ability of borrowers to repay loan. Thus, the impact of inflation on NPLs could be positive or negative (see also Nkusu 2011).

Rule of law indicates the stability of the country. Poor institutional quality, rule of law and corruption destabilize a country and may increase the chances of bankruptcy and/or decrease the efficiency of banks. However, the impact of bank loans on rule of 
law can be positive or negative. For instance, an unstable economy cannot enjoy foreign assistance and easy lending, and thus it relies on domestic funding, which increases output and bad loans.

\section{Methodology}

In this study, correlation between the error term and regressors associated with the introduction of lag values of the dependent variable affects its current value. Hence, the analysis is based on the two-step GMM estimator developed by Arellano and Bond (1991) and Arellano and Bover (1995). Bond et al. (2001)) applied this technique to estimate the growth model in their study and argued that this method can correct unobserved country heterogeneity, omitted variable bias, measurement error and potential endogeneity, which frequently affects growth estimations. Blundell and Bond (1998) used second-or higherorder lags for dependent and other endogenous variables as instruments to check for endogeneity bias, with the validity of the instruments showings the reliability of the GMM estimator. Following Blundell and Bond (1998), Arellano and Bover (1995) and Arellano and Bond (1991), in this study, we also used the Sargan test to assess the validity of the over-identifying restriction in the model and the AR (1) and AR (2) test (autocorrelation test of order one and order two) for zero or no correlation:

$$
\mathbf{N P L}_{i, t}=\mathbf{N P L}_{i, t-1}+\boldsymbol{\beta}_{\mathbf{1}} \text { BANKspecific }_{i, t}+\boldsymbol{\beta}_{\mathbf{2}} \text { MACROspecific }_{t}+\boldsymbol{\mu}_{i}+\mathbf{v}_{t}+\boldsymbol{\varepsilon}_{i, t}
$$

where NPL represents NPLs to gross advances, while BANK-specific contains the bank assets, leverage ratio, loan growth and efficiency ratio of bank $i$ at time $t$. MACROspecific includes GDP growth, unemployment, inflation and rule of law.

\section{H1: Does rapid loan growth enhance the volume of NPLs?}

The first hypothesis examines how loan growth affects the performance of Pakistani banks. The expectation of loan default in the future is associated with an expansion in lending, which may enhance the loan loss provision and build up loan loss reserves. The attitude of borrowers shows that after receiving bank loan they do not default immediately (see the concept of "loan seasoning"; of Berger and Udell 2004). Hence, we hypothesize that previous loan growth translates into an increment in NPLs.

$$
\mathbf{C A P}_{i, t}=\mathbf{C A P}_{i, t-1}+\boldsymbol{\beta}_{\mathbf{1}} \text { BANKspecific }_{i, t}+\boldsymbol{\beta}_{\mathbf{2}} \text { MACROspecific }_{t}+\boldsymbol{\mu}_{i}+\mathbf{v}_{t}+\boldsymbol{\varepsilon}_{i, t}
$$

In Eq. (2), we regress the bank-specific variables and macro-specific variables on solvency.

\section{H2: Does abnormal loan growth affect bank solvency?}

In the second hypothesis, we investigate the impact of loan growth on bank solvency. Capital accumulation by banks is an important reason for unexpected events and higher rating among the competitors. The strength of capital shows the soundness of banks and provides their business with large network. Hence, it is critical to monitor operations across the entire organization. Therefore, reluctant activities aggregate the probability of business risks. Thus, the maximization of capital may enhance loan growth, which leads to a decrease in the ratio of capital to risk-weighted assets. 


\section{Results and Discussion}

Table 1 summarize the bank-specific and macro-specific variables. All variables are documented in percentages except for rule of law, bank size and interest income. Bank size, which uses bank assets as a proxy, and interest income are given in million rupees logarithm, while rule of law is available in the form of an index. Table 2 describes the pair-wise correlation matrix of the dependent variable with the bank-specific and macro-specific variables. The correlation matrix shows that the dependent and explanatory variables are statistically significant at the $5 \%$ level.

By using a dynamic panel data estimation technique, we obtain the results presented in Tables 3 and 4. The Sargan test and AR (1) and AR (2) test results confirm the selection of instrumental variables and zero or no autocorrelation, respectively, which endorses the validity of the results.

The results of this study validate the findings of previous studies of the impact of NPLs and solvency on both macroeconomic and bank-specific factors. Many empirical studies have reported that increasing lending activities ultimately leads to NPLs in future (Salas and Saurina 2002; Cottarelli et al. 2005; Kraft and Jankov 2005; Foos et al. 2010). They find that competition among banks, a short-term profit maximization strategy by managers, and a favorable economic environment are the main causes of rising NPLs.

Columns 1-3 of Table 3 show that bank assets have a negative relationship with NPLs at the $1 \%$ significance level, which suggests that banks try to increase their assets through investment, lending to individuals and businesses and moderating consumer and producer financing schemes during boom periods usually end up with future loan losses and a reduction in bank assets (see Amador et al. 2013; Hess et al. 2009 and Marijana Curak et al. 2013). On the contrary, larger banks have more efficient credit risk management compared with their smaller counterparts (Louzis et al. 2010; Salas and Saurina 2002). However, Kane (2000) and Mishkin (2006) argued that the "too big to fail" effect in large banks can also be behind their higher risk taking.

As expected, there is negative link between the leverage ratio and NPLs which indicates that increases in this ratio create barriers for balance sheet expansion and shrink liquidity in banks. The leverage ratio (column 1 in Table 3), shows significance at the $1 \%$ level, while the regression equation with the macroeconomic variables in columns 2

Table 1 Summary statistics of the variables

\begin{tabular}{llllcll}
\hline Variables & Obs & Mean & Median & Std. Dev. & Min & Max \\
\hline Non-performing loans (\%) & 248 & 15.61 & 11.85 & 15.29 & 0.02 & 78.36 \\
Solvency (\%) & 249 & 19.87 & 14.4 & 16.99 & -6.5 & 100.9 \\
Loan growth (\%) & 239 & 23.09 & 12.2 & 47.33 & -29.1 & 421.4 \\
Leverage ratio (\%) & 251 & 12.46 & 8.73 & 9.9 & 0.23 & 54.31 \\
Efficiency ratio (\%) & 251 & 35.07 & 30 & 17.01 & 0 & 100 \\
Log of Bank assets (Million Rs) & 251 & 18.55 & 18.72 & 1.46 & 14.71 & 21.35 \\
Log of Interest income (Million Rs) & 244 & 15.05 & 15.13 & 1.71 & 6.21 & 18.05 \\
Real GDP growth (\%) & 252 & 3.6 & 3.5 & 1.46 & 1.6 & 6.2 \\
Inflation (\%) & 252 & 10.69 & 10.1 & 2.97 & 7.36 & 17.03 \\
Unemployment (\%) & 252 & 5.80 & 6.0 & 0.38 & 5.2 & 6.24 \\
Rule of law (index) & 252 & -0.86 & -0.86 & 0.06 & -0.98 & -0.74 \\
\hline
\end{tabular}

Sources: State Bank of Pakistan, World Development Indicators and Economic Survey of Pakistan 
Table 2 Pair-wise correlation matrix of the variables

\begin{tabular}{|c|c|c|c|c|c|c|c|c|c|c|c|c|}
\hline No & Variables & 1 & 2 & 3 & 4 & 5 & 6 & 7 & 8 & 9 & 10 & 11 \\
\hline 1 & Non-performing loans & 1.000 & & & & & & & & & & \\
\hline 2 & Solvency & $0.356(0.000)$ & 1.000 & & & & & & & & & \\
\hline 3 & Loan growth & $-0.23^{\mathrm{a}}(0.000)$ & $0.115(0.095)$ & 1.000 & & & & & & & & \\
\hline 4 & Leverage ratio & $0.396^{\mathrm{a}}(0.000)$ & $0.739^{\mathrm{a}}(0.000)$ & $0.135^{\mathrm{a}}(0.048)$ & 1.000 & & & & & & & \\
\hline 5 & Efficiency ratio & $0.416^{\mathrm{a}}(0.000)$ & $0.560^{\mathrm{a}}(0.000)$ & $0.117(0.865)$ & $0.575^{\mathrm{a}}(0.000)$ & 1.000 & & & & & & \\
\hline 6 & Bank assets & $-0.49^{\mathrm{a}}(0.000)$ & $-0.56^{\mathrm{a}}(0.683)$ & $-0.207^{\mathrm{a}}(0.002)$ & $-0.554^{\mathrm{a}}(0.000)$ & $-0.580^{\mathrm{a}}(0.000)$ & 1.000 & & & & & \\
\hline 7 & Interest income & $-0.41^{\mathrm{a}}(0.000)$ & $-0.42^{\mathrm{a}}(0.000)$ & $-0.238^{\mathrm{a}}(0.000)$ & $-0.429^{\mathrm{a}}(0.000)$ & $-0.496^{\mathrm{a}}(0.000)$ & $-0.904^{\mathrm{a}}(0.000)$ & 1.000 & & & & \\
\hline 8 & Real GDP growth & $0.042(0.530)$ & $-0.081(0.225)$ & $-0.130(0.057)$ & $-0.010(0.873)$ & $-0.070(0.264)$ & $-0.043^{\mathrm{a}}(0.494)$ & $-0.079(0.215)$ & 1.000 & & & \\
\hline 9 & Inflation & $-0.119(0.077)$ & $0.072(0.279)$ & $0.245^{\mathrm{a}}(0.00)$ & $0.094(0.135)$ & $0.088(0.162)$ & $-0.102(0.103)$ & $-0.061(0.341)$ & $-0.70^{a}(0.000)$ & 1.000 & & \\
\hline 10 & Unemployment & $0.152^{\mathrm{a}}(0.023)$ & $-0.054(0.420)$ & $-0.248^{\mathrm{a}}(0.000)$ & $-0.103(0.101)$ & $-0.095(0.130)$ & $0.141^{\mathrm{a}}(0.025)$ & $0.106(0.098)$ & $0.518^{\mathrm{a}}(0.000)$ & $-0.843^{\mathrm{a}}(0.000)$ & 1.000 & \\
\hline 11 & Rule of law & $0.051(0.451)$ & $-0.021(0.749)$ & $-0.017(0.801)$ & $0.058(0.386)$ & $-0.011(0.862)$ & $-0.003(0.964)$ & $0.012(0.858)$ & $-0.126(0.058)$ & $0.269^{\mathrm{a}}(0.000)$ & $0.041(0.538)$ & 1.000 \\
\hline
\end{tabular}

Here, $\left({ }^{a}\right)$ indicates the $5 \%$ significance level 
Table 3 Dynamic panel estimation of NPLs with Loan Growth

\begin{tabular}{llll}
\hline Variable & 1 & 2 & 3 \\
\hline Non-Performing Loans & $0.84^{\mathrm{c}}(0.02)$ & $0.78^{\mathrm{c}}(0.05)$ & $0.76^{\mathrm{c}}(0.10)$ \\
Log of Bank Assets & $-0.29^{\mathrm{c}}(0.13)$ & $-5.96^{\mathrm{c}}(3.39)$ & $-4.38^{\mathrm{a}}(1.82)$ \\
Loan Growth & $0.01^{\mathrm{c}}(0.00)$ & $0.01^{\mathrm{a}}(0.00)$ & $0.02^{\mathrm{a}}(0.04)$ \\
Leverage Ratio & $-0.25^{\mathrm{c}}(0.01)$ & $-0.07^{\mathrm{a}}(0.03)$ & $-0.18^{\mathrm{a}}(0.09)$ \\
Efficiency Ratio & $0.05^{\mathrm{c}}(0.01)$ & $0.04^{\mathrm{a}}(0.02)$ & $0.23^{\mathrm{c}}(0.03)$ \\
Rule of Law & $-2.77^{\mathrm{c}}(0.68)$ & $-5.09^{\mathrm{b}}(2.24)$ & $-1.20(4.41)$ \\
GDP growth & & $-1.04^{\mathrm{c}}(0.22)$ & $-1.16^{\mathrm{c}}(0.26)$ \\
Inflation & & $0.15^{\mathrm{a}}(0.10)$ & \\
Unemployment & & $1.51^{\mathrm{a}}(0.79)$ \\
No of Observations & 209 & 209 & 209 \\
Sargan Test & $21.19(0.56)$ & $16.42(0.99)$ & $16.13(1.00)$ \\
AR(1) & $-2.10(0.03)$ & $-2.46(0.01)$ & $-1.90(0.05)$ \\
AR(2) & $-1.49(0.13)$ & $-1.26(0.20)$ & $-1.21(0.22)$ \\
\hline Notes: ${ }^{\mathrm{c}, \mathrm{b}}$ and ${ }^{\mathrm{a}}$ indicate significance at the 1,5 and 10\% levels, respectively &
\end{tabular}

and 3 modifies the results at the 10\% significance level. These results highlight that bad governance and high inflation trigger bad future debts.

Similarly, in columns 1-3 of Table 3, we find a positive and significant relationship between NPLs and loan growth, which suggests that an increase in future loan losses enhances financial fragility. ${ }^{5}$

The efficiency ratio has a positive and direct relationship with NPLs, which suggests that the loan loss provision increases because of extensive lending activities. On the contrary, during recessions, banks must maintain their fixed expenses by decreasing their returns from limited business activities. In both cases, NPLs raise bank costs. In columns 1 and 3, we see that the links between managerial efficiency and NPLs are positive and significant at the $1 \%$ level, while, the efficiency ratio is significant at the 10\% level (column 2).

The relationship between rule of law and NPLs is negative as expected. One possibility is that in developing countries, financial firms do not abide by the rule of law because of political influence or corruption. Another possibility is that while financial

Table 4 Dynamic panel estimation of solvency and loan growth

\begin{tabular}{llll}
\hline Variables & 1 & 2 & 3 \\
\hline Solvency & $0.71^{c}(0.02)$ & $0.72^{c}(0.01)$ & $0.75^{c}(0.02)$ \\
Log of Bank Assets & $5.10^{c}(0.76)$ & $3.27^{\mathrm{b}}(1.06)$ & $2.91^{\mathrm{c}}(0.72)$ \\
Loan Growth & $-0.08^{\mathrm{c}}(0.01)$ & $-0.07^{\mathrm{c}}(0.00)$ & $-0.06^{\mathrm{c}}(0.00)$ \\
Efficiency Ratio & $-0.05^{\mathrm{c}}(0.01)$ & $-0.03^{\mathrm{a}}(0.01)$ & $-0.05^{\mathrm{b}}(0.02)$ \\
Rule of Law & & $10.54^{\mathrm{c}}(1.19)$ & $16.23^{\mathrm{c}}(1.49)$ \\
GDP growth & & $1.04^{\mathrm{c}}(0.09)$ \\
No of Observations & 209 & 209 & 209 \\
Sargan Test & $24.04(0.97)$ & $18.53(0.99)$ & $24.09(0.97)$ \\
AR(1) & $-2.10(0.03)$ & $-2.15(0.03)$ & $-2.07(0.03)$ \\
AR(2) & $-0.38(0.70)$ & $0.16(0.87)$ & $0.09(0.92)$ \\
\hline
\end{tabular}

Notes: ${ }^{c}{ }^{b}$ and ${ }^{a}$ indicate significance at the 1,5 and $10 \%$ levels, respectively 
sectors follow standards, other dimensions of governance are worse, which weaken overall governance.

In this context, a worse rule of law provides an easy escape for influential creditors and raises the volume of NPLs. In column 1 of Table 3 rule of law is significant at the $1 \%$ level compare with the $5 \%$ level in column 2 .

The association between GDP growth and NPLs is found to be negative, again confirming the findings of many empirical studies (Foos et al. 2010; Khemraj and Pasha 2009; Salas and Saurina 2002). According to the literature, GDP growth usually increases the incomes of households and firms, which ultimately enhances saving and investment capacity. On the contrary, the ability to repay loans increases, which reduces the volume of bad loans (Khemraj and Pasha 2009).

The direct relation between NPLs and inflation suggests that recessionary period deteriorate underwriting standards and reduces the ability of borrowers to repay loans because of the higher prices of goods. Column 2 in Table 3 shows that the coefficient of inflation is positive and significant at the $10 \%$ level. This finding also indicates that higher inflation triggers financial distress and bad loan growth (eg, Domac and Martinez-Peria 2003; Hutchison 2002).

The positive connection between unemployment and NPLs is consistent (Bofondi and Ropele; 2011), which suggests that seasonal employment or low-income borrowers have higher default rates because of the higher risk of unemployment and consequently an inability to repay their loan obligations.

In Table 4, we regress the bank-specific and macroeconomic variables on solvency. We find a positive and significant relation between solvency and bank size at the $1 \%$ level (see column 1 to 3 ). This finding suggests that diversification and effective monitoring measures increase bank size to cover unexpected events and reduce the chances of insolvency (see also Baradwaj et al. 2014; Marijana Ćurak et al. 2013).

Stable and vibrant balance sheets encourage banks to raise income through controlled loan growth. However, attitude towards more returns or profits makes easier credit more accessible for individuals and businesses, which usually transforms into future loan losses and a decrease in bank capital. Thus, bad loan growth decreases the solvency of banks. This result is consistent with previous findings that propose an indirect relationship between solvency and loan growth (Messai and Jouini 2013; Baradwaj et al. 2014).

The efficiency ratio has a significant negative relationship with solvency at the 1,5 and $10 \%$ level (see columns 1 to 3, respectively). Lending booms or favorable economic environments, banks enjoy higher profits. Therefore, the magnitudes of the loan loss provision and fixed operating costs are lower than profits and banks enjoy strong capital. The governance indicator suggests that strong institutions, a sound rule of law, and stable political conditions provide the best opportunities for businesses, which also supports fearless financing by financial institutions (Adams 2011). The relation between rule of law and solvency is significant positive at 1\% level (see columns 2 and 3), which suggests that during stable economic and political periods, financial firms expand their business activities to harness high returns. Indeed, as the ability to repay loans becomes stronger in growing economies banks enjoy healthy balance sheets. Hence, GDP growth is positively associated with solvency at the $1 \%$ level as indicated in column 3 of Table 4 (eg, Foos et al. 2010). 


\section{Conclusions}

The reforms of bank structure and period of favorable economic growth in Pakistan during the mid-2000s led to a lending boom. Competition among banks, expansion opportunities for businesses and technological advancement all laid the platform for widespread loan supply to borrowers.

However, previous studies have found that rapid loan supply worsens balance sheet strength. Again this background this study examined whether higher loan growth always transforms into higher loan losses under the influence of important macroeconomic indicators such as GDP growth, inflation and unemployment. Many studies have suggested that borrowers do not default immediately after receiving a loan; rather, it usually takes 3 years or more (Berger and Udell 2004). Similarly, Foos et al. (2010) and Salas and Salas and Saurina (2002) revealed that the growth in abnormal loans in previous years is directly associated with loan losses at both the aggregate and the individual bank level.

This study examined the impacts of loan growth on the NPLs and solvency of 32 banks in Pakistan over 2006-2014. We found that loan growth in the banking sector is affected by bank-specific and macro-specific variables. The presented findings, support those of existing empirical studies, which suggest that abnormal loan growth during a lending booms increases the ratio of NPLs to gross advances and that rapid growth in bad loans diminishes the capital ratio, which indicates a decrease in bank solvency.

These findings suggest that the benefits of loan growth can be strong and effective if banking regulations and supervision are in place as well as that massive loan growth and weak prudential regulations are the main factors behind the vulnerability of the banking sector. We recommend strong and prudential regulations and an increase in the capital requirement policy for rapidly growing banks because the problem of abnormal loan growth cannot be detected at the current time.

\section{Endnotes}

${ }^{1}$ (Rousseau and Wachtel 2002; Wachtel 2001 and Levine et al. 2000).

${ }^{2}$ Pattarathammas and Mongkonkiattichai (2012) examined the banks performance in different region of Asia and found that in the expansionary period, excessive loan growth did not enhance the level of loan losses due to strong supervision and screening procedure. They also suggested that supervision by regulatory authorities and implementation of risk management, support the expansion of financial institution business or lending during the period of business expansion in order to accumulate bank profit.

${ }^{3}$ See Further, Marijana Curak et al. (2013) analyzed the banks specific and macroeconomic variables of Southeastern Europe and found the positive relationship between solvency and bad loans because lending in the presence of risky activities trigger more capitalization in past years, experience increase non-performing loans in current year. Furthermore, results documented that the higher inflation, lower economic growth and higher interest rate are connected with higher non-performing loans.

${ }^{4}$ See further for number of banks in different years http://www.sbp.org.pk/publications/schedule_banks/Dec-2014/Appendices.pdf.

${ }^{5}$ (See, Foos et al. 2010; Marijana Curak et al. 2013; Sinkey and Greenwalt (1991). 


\section{Acknowledgements}

We are grateful to Zeeshan Ahmed Khan, Senior Vice President (Risk Policy and Analytics) at Faysal Bank Ltd. And Syed Mujtaba Zafar, Research Scholar, Victoria University, Australia for their valuable comments on financial stability and banking regulations in Pakistan on earlier draft of this paper.

\section{Authors' contribution}

The main author of this research paper in MK. SFI helped me in result estimation and interpretations. KI supported me in review of literature and modelling. All authors read and approved the final manuscript.

\section{Competing interests}

This paper's findings, interpretations, recommendations and conclusion are those of the authors and do not necessarily reflect the view of central bank, commercial bank or any other policy making institutions of the country. Authors of the paper understand "Financial Innovation" Journal policy on declaration of interest and declare that he has no competing interest.

Received: 30 June 2016 Accepted: 29 November 2016

Published online: 08 December 2016

\section{References}

Adams RB (2011) Governance and the financial crisis. International Review of Finance, Vol-12, Issue 1, March 2012, page 7-38. http://onlinelibrary.wiley.com/doi/10.1111/j.1468-2443.2011.01147.x/full.

Allen F, Gale D (2003) Competitions and financial stability. In: Paper presented at World Bank conference on bank concentration and competition, April 3-4 Washington

Altunbas Y, Gambacorta L, Marques-lbanez D (2010) Bank risk and monetary policy. J Financ Stab 6:121-9

Amador JS, Gómez-González JE, Pabón AM (2013) Loans growth and baaaanks' risk: new evidence

Arellano M, Bond S (1991) Some tests of specification for panel data: Monte-Carlo evidence and an application to employment equations. Rev Econ Stud 58:277-97

Arellano M, Bover O (1995) Another look at the instrumental variable estimation of error-components models. J Econ 68:29-51

Baradwaj BG, Flaherty MV, Shao Y (2014) The impact of lending growth on the riskiness of Chinese banks. Chin Econ 47(5-6):29-49

Bencivenga V, Smith B (1991) Financial intermediation and endogenous growth. Rev Econ Stud 58:195-209

Berge TO, Boye KG (2007) An analysis of bank's problem loans. Norges Bank Econ Bull 78:65-76

Berger AN, Udell GF (2004) The institutional memory hypothesis and the procyclicality of bank lending behavior. J Financ Intermed 13:458-95

Blundell R, Bond S (1998) Initial conditions and moment restrictions in dynamic panel data models. J Econom 87:115-43

Bofondi M, Ropele T (2011) Macroeconomic determinants of bad loans: evidence from Italian banks. http://www. bancaditalia.it/pubblicazioni/qef/2011-0089/QEF_89.pdf.

Bond S, Hoeffler A, Temple J (2001) GMM estimation of empirical growth models

Cottarelli C, Dell'Ariccia G, Vladkova-Hollar I (2005) Early birds, late risers, and sleeping beauties: Bank credit growth to the private sector in Central and Eastern Europe and in the Balkans. J Bank Financ 29:83-104

Cucinelli D (2015) The impact of non-performing loans on bank lending behavior: evidence from the italian banking sector. Eurasian J Bus Econ Manag 8(16):59-71

Dell'Ariccia G, Marquez R (2006) Lending Booms and Lending Standards. J Financ 61:2511-46. doi:10.1111/j.1540-6261. 2006.01065.x

Domac I, Martinez-Peria MS (2003) Banking crisis and exchange rate regimes: is there a link. J Int Econ 61(1):41-72

Foos D, Norden L, Weber M (2010) Loan growth and riskiness of banks. J Bank Financ 34:2929-40

Gourinchas PO, Valdes R, Landerretche O (2001) Lending booms: Latin America and the World. Economia 47-99. doi:10. 3386/w8249

Hess K, Grimes A, Holmes M (2009) Credit losses in Australasian banking. Econ Rec 85(270):331-43

Hutchison M (2002) European Banking Distress and EMU: Institutional and macroeconomic risks. Scand J Econ 104(3):365-89

Johnson S, Boone P, Breach A (2000) Corporate governance in the Asian financial crisis. J Financ Econ 58(1-2):141-86

Kane EJ (2000) Incentives for banking mega mergers: what motives might regulators infer from event-study evidence? Part 2: What should central banks do? J Money Credit Bank 32:671-701

Khemraj T, Pasha S (2009) The determinants of non-performing loans: an econometric case study of Guyana. In: Presented at the Caribbean Centre for Banking and Finance Bi-annual Conference on Banking and Finance. St. Augustine, Trinidad. https://mpra.ub.uni-muenchen.de/53128/1/MPRA_paper_53128.pdf.

Kraft E, Jankov L (2005) Does speed kill? Lending booms and their consequences in Croatia. J Bank Financ 29:105-21

Leaven L, Majnoni G (2003) Loan loss provisioning and economic slowdowns: Too much, too late. J Financ Intermed 12:178-97

Levine R (2002) Bank-based or market-based financial system: which is better? In: NBER working paper series 9138

Levine R, Loayza N, Beck T (2000) Financial intermediation and growth: causality and consequences. J Monet Econ 46(2000):31-77

Louzis DP, Vouldis AT, Metaxas VL (2010) Macroeconomic and bank-specific determinants of non-performing loans in Greece: a comparative study of mortgage, business and consumer loan portfolios, Bank of Greece, Working Paper, no 118

Marijana Ćurak M, Pepur S, Poposki K (2013) Determinants of non-performing loans - evidence from Southeastern European banking systems". Banks Bank Syst 8(1):45-54

Messai AS, Jouini F (2013) Micro and macro determinants of non-performing loans. Int J Econ Financ Issues 3(4):852-60

Mishkin FS (2006) How big a problem is too big to fail? A review of Gary Stern and Ron Feldman's "Too big to fail: the hazards of bank bailouts. J Econ Lit 44:988-1004

Nkusu M (2011) Nonperforming loans and macrofinancial vulnerabilities in advanced economies. IMF Working Paper 11/161 
Pattarathammas S, Mongkonkiattichai S (2012) Loan growth and risk of Asian Financial Institutions after the Asian Financial Crisis October 19, 2012

Pelozo JAI (2008) Loans, risks, and growth: the role of government and public banking in Paraguay. Q Rev Econ Finance 48(2):307-19

Rajaraman I, Vasishtha G (2002) Non-performing loans of PSU Banks: some panel result, economic and political weekly. pp 429-435

Rousseau PL, Wachtel P (2002) Inflation threshold and the finance-growth nexus. J Int Money Financ 21:277-93

Salas V, Saurina J (2002) Credit risk in two institutional regimes: Spanish commercial and saving banks. J Financ Serv Res 22:203-24

Sinkey J, Greenwalt M (1991) Loan loss experience and risk-taking behavior at large comercial banks. J Financ Serv Res $5 \cdot 43-59$

Tahir SH, Shehzadi I, Ali I, Rizwanullah M (2015) Impact of bank lending on economics growth in Pakistan: an empirical study of lending to private sector. Am J Ind Bus Manag 5:565-76

Tinoco-Zermeño MA, Venegas-Martínez F, Torres-Preciado VH (2014) Growth, bank credit, and inflation in Mexico: evidence from an ARDL-bounds testing approach. Lat Am Econ Rev 23:8

Wachtel P (2001) Growth and finance: what do we know and how do we know it? Int Financ 4(3):353-62

Submit your manuscript to a SpringerOpen ${ }^{\circ}$ journal and benefit from:

- Convenient online submission

- Rigorous peer review

- Immediate publication on acceptance

Open access: articles freely available online

- High visibility within the field

- Retaining the copyright to your article

Submit your next manuscript at $>$ springeropen.com 